Selvom der ikke umiddelbart er nogen dialog mellem indlæggene i bogen, så er der det alligevel på den måde, at indlæggene hver fra sit udgangspunkt udtrykker forskelle og ligheder mellem de internationale initiativer og historien om den danske folkehøjskole og Grundtvig.

Indlæggene i bogen viser, at det går ganske godt for folk udenfor Danmark med at få inspiration til oplysning og uddannelse gennem interesse for den danske folkehøjskoles historie og /eller Grundtvig. Det sker ad mangfoldige veje, der ikke lader sig styre. Det fremgår af bogen, at folkehøjskolen ikke er en koncern, der opretter filialer rundt om i verden, men en levende tradition. Problemet med, om det nu også sker på den rette måde og på det rigtige grundtvigianske grundlag, er måske mest et problem, der opstår i det øjeblik, det gøres til genstand for den danske folkehøjskoleforskning?

Ønsker man som forsker at arbejde henimod forståelse for en tradition, får man den måske mere ved at se på, hvordan den lever og skabes, end ved at forsøge at skabe orden i den. Denne tilgang ligger også i denne bog, og i det lys er det befriende, at indlæggene får lov at stå for sig selv, og at læseren har lov til at vælge, hvilket niveau hun vil læse bogen på: som et udtryk for overvejelserne fra dansk side over, hvorledes man kortlægger en traditions indtagelse af verden, eller hvordan man ude $\mathrm{i}$ verden forholder sig til en viden om en skoletradition i Danmark.

\title{
Grundtvig og folkeviljen, Hal Koch og Krogerup Højskole
}

\author{
Af Vagn Wåhlin
}

Tine Damsholt: Troen på folkeviljen. Analyse af en tradition $i$ dansk demokratiopfat-

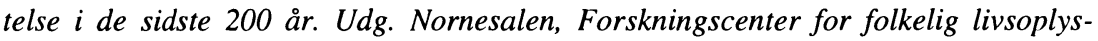
ning, Kroghs forlag, Vejle 1994. 72 sider. $128 \mathrm{kr}$.

Den foreliggende, prisværdigt kortfattede og læsevenlige bog er udsprunget af den stadige debat og indre selvransagelse om demokratiets udspring, væsen og funktion, som må være et kendemærke for et sandt folkestyre, herunder det danske. Som forskningsstipendiat under projekt »Folkelighed og folkestyre « ved forskningscentret for folkelig livsoplysning, Ollerup, har forfatteren (TD) med baggrund i sin specialeafhandling fået lejlighed til at uddybe og fremlægge en række punktstudier omkring centrale kulturpersonligheders forståelse af og betydning for den folkelige debat som baggrund for den politisk udtrykte folkevilje.

Bogen er derfor opdelt $i$ tre hovedafsnit og en afslutning. I den sidste føres en række tanker frem til nutidens problematik omkring folkestyret bl.a. eksemplificeret ved forholdet til den Europæiske Union. Herved er bogen nyttiggiort som baggrund 
for en kvalificeret debat i folkelige sammenhænge - på højskoler, i den fri voksenundervisning m.v. Alligevel finder jeg, at bogens væsentlige kvaliteter ligger i de tre historisk orienterede hovedkapitler: I. Folket og folkeviljens fødsel, s.6-25, om de udenlandske og danske filosofisk-politiske forudsætninger for det repræsentative demokratis gennemslag herhjemme ved midten af 1800-tallet; II. Kongehånd og folkestemme, s.26-42, med særlig vægt på at udrede den specielle grundtvigsk prægede forståelse af folket og dets deltagelse i samfundets styre; III. Hal Koch og den demokratiske livsform, s.43-64, hvor den grundtvigske virkningshistorie i højskoler og politisk kultur med Hal Koch som ledefigur og Krogerup Højskole som institution står i centrum.

Det trykte kildemateriale er helt rimeligt det væsentlige og er gengivet i litteraturlisten bagest. Som baggrund for selvstudier er listen dog for kortfattet. Især de store kildeudgivelser af Grundtvigs omfattende produktion burde have været anført med henvisning til, hvor de benyttede originale skrifter fra 1830erne og 1840erne er at finde, også når man bor i Brønderslev. Tilsvarende burde Grundtvig Studier, Vartovbogen, Højskolebladet m.fl. have været introduceret og ikke blot som vedrørende først- og sidstnævnte være refereret ukommenteret. Vedrørende faglitteraturen må der naturligvis foretages et udvalg. Alligevel finder jeg det uheldigt, at de udmærkede introduktioner på dansk til fx Hobbes og Hume ikke nævnes, eller at det i denne sammenhæng centrale arbejde vedrørende de sidste 200 år, Dansk Identitetshistorie, I-IV (1991) end ikke antydes, ligesom forfatterens egen magisterafhandling, nævnt note 9, ikke er at finde. Omvendt er Edvard Holms fremragende afhandlinger vedrørende det sene 1700-tal og Hal Kochs egne arbejder medtaget i tilfredsstillende omfang. Endeligt kunne læseren godt have undværet nogle mindre vægtige indlæg.

Citaterne er velvalgte og illustrative og TD gengiver dem prisværdigt med original bogstavering. Dog er der nogle svipsere, s. 38 nederst har et »på« sneget sig ind i stedet for »paa«, og $s .41$ nederst er $\gg V_{«}$ og $\gg D \ll i$ 'Verden' og 'Dele' blevet minimeret til »V« og »d«. Disponering og fremlæggelse af det ofte vanskelige stof er klar. TD undgår på behagelig vis såvel akademiske snurrepiberier som over-folkelige udtryksmåder i teksten, uden at det derfor fornægter sig, at hendes hjerte - som forventeligt med hendes baggrund - er åbent over for det grundtvigsk-folkelige livssyn.

I første hovedafsnit peges der overbevisende på, at kontrakt-teorien - dvs at folket og fyrsten havde indgået en kontrakt om styreformen, hvor fyrsten skulle lede samfundet til helhedens bedste, og folket skulle lyde den gode leder - vandt bred anerkendelse under enevælden i Danmark i 1700-tallet. Parallelt hermed vandt John Locke's opfattelse af de tre lovtyper tilsvarende udbredelse:

1) Den guddommelige lov, der målte synd og pligt,

2) Den civile/borgerlige lov, der målte forbrydelse og lovlydighed/uskyldighed og

3) Den filosofisk/moralske lov, der udmålte dyd og last (s.10).

Styret måtte efter borgerskabets opfattelse lade sig vejlede af den offentlige mening, som denne udformedes gennem en kultiveret debat på tryk og i diverse foreninger. Suveræniteten lå i sidste ende hos folket; men hvem repræsenterede på bedste måde 
dette ubestemmelige folks uhåndgribelige vilje? Forfatteren anfører med rette, at dette sidste problem stadigt er brændende; men man havde gerne tillige set en diskussion af, at med religiøsitetens og moral-filosofiens genkomst på mange samfundsområder er det et problem i nutiden, at egentlige domstole kun findes vedrørende Locke's pkt 2 og dér har udviklet en så ekstrem og bevidst mangel på lydhørhed over for indflydelser fra de religiøse og moralske livssfærer, at stadigt større samfundsgrupper bevidst sætter sig ud over de borgerlige retsregler og åbenlyst misbruger den borgerlige liberalitet. Altså: hvad skal vi i dag sætte i stedet for en kirke, som har mistet synden og en presse, som har mistet dyden?

Bag folkets vilje - hvordan den end konkretiseres - må der findes et 'folkets sindelag' (s.25), en klangbund, hvor Locke's pkt. ét og tre samspiller med pkt. 2 for at skabe sammenhæng og medmenneskelighed i det faktiske samfundsliv. At finde og vejlede dette 'folkets sindelag' var, efter TDs opfattelse, Grundtvigs og Hal Kochs visioner og livsmål (s.26).

I andet hovedafsnit $g ø r$ forfatteren berettiget op med den tidligere udbredte opfattelse, at Grundtvig 1848 foretog en kolbøtte fra enevoldsmand til demokrat. Ved en grundig gennemgang af de væsentligste samfundsmæssige og politiske af Grundtvigs skrifter fra 1830erne og 1840erne viser hun, hvorledes han allerede tidligt fremlagde de opfattelser, som gjorde, at han i 1848 kunne gå ind i den politiske kamp på det repræsentative demokratis vilkår. For ham måtte formen, konstitutionen, tilpasses historien og samtidens vilkår - og var altså foranderlig - så den gav den bedst mulige ramme for folkets liv. Hans mistillid til partipolitiske rigsdagsmanøvrer var grundfæstet, mens hans tillid til gunstige resultater af en grundig, levende og fri offentlig debat blandt oplyste og samfundsengagerede borgere var omvendt tilsvarende stor $i$ det, han kaldte 'den frie folkestemme'. Men den 'frie folkestemme' opstod ikke ud af det blå, den kunne formes eller misformes. Derfor var højskolen og en 'folkelig dannelse' et uundværligt led i hans politiske tænkning.

I tredje hovedafsnit begyndes med situationen ved Besættelsen i 1940, hvor det blev klart for Hal Koch og mange med ham, at såvel 'danskheden' som det demokratiske sindelag var på spil og måtte forsvares og udbygges. Dette forsvar skulle ikke ske ved at fornægte modsætninger i livsholdninger og samfundssyn, men netop ved gennem samtalen at lære at respektere og forvalte flersidigheden. Det repræsentative demokrati var formen, det væsentlige var 'sindelaget'. Som samfundsindivid - og dermed egentlig som menneske - var dette på én gang at være dansk og samtidig være folkeligt-demokratisk for Hal Koch to sider af samme sag.

I en række sammenhænge arbejdede Hal Koch med held, men også under modstand, for at udbrede sin forståelse af folkelighed, demokrati og borgernes aktive medansvar for samfundets trivsel og udvikling. Viljen og evnen til at gå fra tale til handling og virkeliggørelse var central i hans virke. Over for Grundtvigs - af Koch hævdede - accentuering af 'kulturen' som det sammenbindende kit $i$ et folk og en nation stillede Koch det politiske, det konkrete daglige samspil, at man »er sat her sammen«, som det væsentligste $i$ at kunne og ville skabe og ville leve et folkefællesskab.

Det sene 1700-tals danske, Grundtvig og hans følgesvende og Hal Koch tog alle ifølge TD udgangspunkt $\mathrm{i}$ kontraktteorien og $\mathrm{i}$ at suveræniteten $\mathrm{i}$ sidste ende ligger hos folket og kun kan delegeres, men aldrig afgives. For 1700-tallets samfundstænkere som for Grundtvig og Hal Koch måtte individet oplyses og opdrages til 
bevidsthed om samfundet og dets muligheder, før den enkelte ved viljeshandlinger kunne påtage sig medansvar for samfundets trivsel og udvikling og dermed frivilligt påtage sig folkefællesskabet.

Forfatteren har i bogen påvist en sådan kontinuitet gennem 200 år - andre ville kunne pege på brudflader og diskontinuitet.

Tine Damsholt har skrevet en lille bog af stor betydning for forståelsen af dansk politisk kultur.

\section{Den nordiske mytologi, folkehøjskolen og livsoplysningen}

\section{Af Kim Arne Pedersen}

Jens Peter Agidius: Vølvens Spådom på dansk. En litteratur - og åndshistorisk undersøgelse. Studier fra Sprog - og Oldtidsforskning. København 1978. 137 s.

Jens Peter Agidius: Bragesnak 1. Nordiske Myter og Mytefortalling i Dansk Tradition (indtil 1910). Odense Universitetsforlag. Odense 1985. 255 s. 99 kr.

Jens Peter Agidius: Bragesnak 2. Den mytologiske tradition i dansk folkeoplysning. Odense Universitetsforlag. Odense 1992. 270 s. 240 kr.

Jens Peter Agidius: Christian Flor. Padagogen, politikeren, folkeoplyseren. En biografi. Odense Universitetsforlag 1994. 386 s. $250 \mathrm{kr}$.

Blandt de mange bøger, som er fremkommet i forbindelse med højskolejubilæet $\mathrm{i}$ 1994, finder vi også en omfattende og grundig skildring af Rødding højskoles stifter og leder, det danske sprogs forkæmper Christian Flor. Forfatteren til dette værk er Jens Peter Ægidius, magister i nordisk litteratur ved Odense Universitet, senere forsker sammesteds og i en periode dansk lektor i Kiel, - og dermed indehaver af et embede, der peger tilbage til Flors stilling ved samme universitet over hundrede år tidligere. Ægidius har indledt sin forskerkarriere midtvejs i livet, men har alligevel formået at udsende en række værker, der fremstiller den nordiske mytologis rolle $\mathrm{i}$ dansk åndsliv fra det 18. århundrede og frem til i dag. Det er imidlertid ikke kun på baggrund af den sent indledte karriere, disse værker imponerer. Ægidius’’ bøger vidner om hans omfattende viden og om evne til at gøre denne viden tilgængelig i en klar og fast form, uden at der gives køb, når det drejer sig om kildemæssigt belæg og omhu for detaljen. Ægidius er god til at få de mange oplysninger med, så god, at hans fremstillinger $\mathrm{i}$ ny og næ tenderer mod den kronologisk ordnede materialesamling.

Det ville dog være forkert at hævde, at Ægidius’ forskning ikke er båret af et samlende synspunkt. Det fremgår af adskillige tekstsammenhænge i hans bøger, at Ægidius personligt føler sig forpligtet på romantikkens interesse for det oprindelige, 